Review

\title{
Update on Treatment Guideline in Fibromyalgia Syndrome with Focus on Pharmacology
}

\author{
Sanam Kia ${ }^{1, *}$ and Ernet Choy ${ }^{2}$ \\ 1 Abertawe Bro Morgannwg University Health Board NHS Trust, Neath Port Talbot Hospital, Port Talbot, \\ Wales SA12 7BX, UK \\ 2 Institute of Infection and Immunity, Cardiff University School of Medicine, Cardiff University, \\ Tenovus Building, Heath Park, Cardiff CF14 4XN, UK; Ernest.choy@wales.nhs.uk \\ * Correspondence: Sanam.kia@wales.nhs.uk; Tel.: +44-017-927-03102
}

Academic Editor: Kim Lawson

Received: 23 February 2017; Accepted: 26 April 2017; Published: 8 May 2017

\begin{abstract}
Fibromyalgia syndrome (FMS) is a chronic condition with unknown aetiology. The pathophysiology of the disease is incompletely understood; despite advances in our knowledge with regards to abnormal central and peripheral pain processing, and hypothalamo-pituitary-adrenal dysfunction, there is no clear specific pathophysiological therapeutic target. The management of this complex condition has thus perplexed the medical community for many years, and several national and international guidelines have aimed to address this complexity. The most recent guidelines from European League Against Rheumatism (EULAR) (2016), Canadian Pain Society (2012), and The Association of the Scientific Medical Societies in Germany (AWMF) (2012) highlight the change in attitudes regarding the overall approach to FMS, but offer varying advice with regards to the use of pharmacological agents. Amitriptyline, Pregabalin and Duloxetine are used most commonly in FMS and though modestly effective, are useful adjunctive treatment to non-pharmaceutical measures.
\end{abstract}

Keywords: fibromyalgia syndrome (FMS); guideline; pharmacology; therapy

\section{Introduction}

Fibromyalgia syndrome (FMS) is a chronic condition characterised by generalized body pain, fatigue, sleep disturbance, impaired cognition, and anxiety with unknown aetiology. Potential causes include genetic, neurologic, psychologic, sleep and immunologic factors [1]. Fibromyalgia has an estimated prevalence of $0.5 \%$ to $5.8 \%$ in North America and Europe [2]. The pathophysiology of the disease is not clearly understood, although abnormality in pain processing at various levels (peripheral and central), sleep impairment, dysregulation of the hypothalamo-pituitary-adrenal axis, and abnormalities of the autonomic nervous system have been identified as contributory factors. Despite our increased understanding of the condition, there are no objective diagnostic tests. Diagnosis is often made by exclusion of other conditions such as neurological syndromes and depression. This lack of a single unifying pathophysiology is mirrored by a complex and non-specific approach to management.

The first clinical criteria for the diagnosis of FMS was set in 1990 by the American College of Rheumatologist (ACR) [3]. It was based on widespread body pain (defined as the pain affecting both sides of the body above and below the waist) for at least three months plus tenderness in at least 11 out of 18 tender points. In 2010, these criteria were updated to change the focus towards a subjective widespread body pain index (WPI) and symptom severity scale (SS), taking into account cognitive symptoms, sleep, fatigue and additional somatic symptoms [4].

Despite our greater understanding of the disease, there is no definitive treatment for FMS and various guidelines for treatment exist, which are at time contradictory in their advice. The 
approach to managing FMS has evolved over recent years, as reflected by recently updated guidelines published by European League Against Rheumatism (EULAR) [5]. Increasingly, there is a focus on non-pharmacological therapies for FMS, such as cognitive behavioural therapy, exercise therapy, hydrotherapy, and acupuncture. Although these advances may have aided the management of FMS, providing clinicians and patients with alternative therapy avenues to pursue, pharmacology remains the mainstay of therapy. Therapeutic classes and targets of pharmacologic therapy in FMS are varied, including classical analgesic therapies such as opiates, and ranging to antidepressants, anticonvulsants, and others. This wide range of therapies often leads to confusion in the clinic, and the evidence supporting one therapy over another is limited. This is reflected in the guidance, which offers evidence for the potential utility of each class of pharmacological intervention, but does not necessarily support one form over another and certainly does not provide a treatment hierarchy. Compounding these difficulties, there is also a significant degree of variability between the guidance.

In this paper, we will review the most recent national and international guidelines for the management of fibromyalgia, with a particular focus on the pharmacological agents. We will set out the evidence for the use of each class of pharmacological agent derived from each guideline, and form a synthesis of the evidence with the aim of assisting clinicians in gaining an overview of each intervention based on the agent, rather than divided by guideline. The process and quality of the guideline drafting process will also be assessed.

\section{The Guidelines}

The EULAR 2016 guidelines [5] were developed by 18 members from 12 European countries including clinicians, no-clinical scientists, patient representatives, and allied health professions. The guideline is based upon synthesis of systematic reviews (with or without meta-analysis) with pain as the primary outcome, although fatigue, sleep, and daily function were also used as secondary endpoints. The authors used the Grading Recommendations Assessment, Development, and Evaluation system (GRADE) for making recommendations, with the strength of recommendations based on desirable and undesirable effects. This is a four-point scale: strong for/weak for/weak against/strong against (Table 1). All participants then voted on the level of agreement. In their 10 recommendations, exercise therapy has been given the highest level of recommendation which is a stark difference from the previous guideline [6] where pharmacological treatment was considered to be the focus of therapy. Initial management should involve patient education and focus on nonpharmacological therapies. In non-responsive patients, pharmacological therapies should be added especially to those with sleep or mood disturbances. 
Table 1. Comparison of the categorization of evidence and recommendations of the four guidelines used for therapy/prevention/aetiology and adverse reactions.

\begin{tabular}{|c|c|c|c|}
\hline Level of Evidence/Recommendation & AWMF 2012 & Canadian Guideline 2012 & EULAR 2016 \\
\hline Evidence level I & $\begin{array}{l}\text { Ia-SR (with homogeneity) of RCTs } \\
\mathrm{Ib} \text {-individual RCTs (with narrow } \\
\text { confidence intervals) } \\
\text { Ic-All or non }\end{array}$ & $\begin{array}{l}\text { Systematic review of randomised trials } \\
\text { or n-of- } 1 \text { trials (treatment) } \\
\text { Systematic review of inception cohort } \\
\text { studies (outcome) }\end{array}$ & RCTs (double blind) \\
\hline Evidence level II & $\begin{array}{l}\text { IIa-SR (with homogeneity) of cohort } \\
\text { studies } \\
\text { IIb—-single cohort studies (including low } \\
\text { quality RCT; e.g., }<80 \% \text { follow up post } \\
\text { observation rate) } \\
\text { IIc—results search; ecological studies }\end{array}$ & $\begin{array}{l}\text { Randomised trial or (exceptionally) } \\
\text { observational study with dramatic effect } \\
\text { (treatments) } \\
\text { Inception cohort studies (outcome) }\end{array}$ & $\begin{array}{l}\text { Randomised double blind } \\
\text { crossover trials }\end{array}$ \\
\hline Evidence level III & $\begin{array}{l}\text { IIIa-SR (with homogeneity) of } \\
\text { case-control studies } \\
\text { IIIb-single case-control studies }\end{array}$ & $\begin{array}{l}\text { Non randomised controlled } \\
\text { cohort/follow-up study (treatment) } \\
\text { Cohort of control arm of randomised } \\
\text { trial (outcome) }\end{array}$ & Randomised single blind trials \\
\hline Evidence level IV & $\begin{array}{l}\text { Case series and poor quality cohort and } \\
\text { case-control studies }\end{array}$ & $\begin{array}{l}\text { Systematic review of case control studies } \\
\text { or historically controlled studies } \\
\text { (treatments) systematic review of } \\
\text { case series }\end{array}$ & Randomised open trials \\
\hline Evidence level V & Expert opinion without critical analysis & Opinion & Non randomised open trials \\
\hline \multicolumn{4}{|l|}{ Recommendations } \\
\hline Strength A & $\begin{array}{l}\text { Based on evidence level 1(subject to } \\
\text { up/downgrade) }\end{array}$ & Consistent level I studies & Strong for \\
\hline Strength B & $\begin{array}{l}\text { Based on evidence level } 2 \text { (subject to } \\
\text { up/downgrade) }\end{array}$ & $\begin{array}{l}\text { Consistent level II Or III studies, or } \\
\text { extrapolations from level } 1 \text { studies }\end{array}$ & Weak for \\
\hline Strength C & $\begin{array}{l}\text { Based on evidence levels } 3,4,5 \text { (subject to } \\
\text { up / downgrade) }\end{array}$ & $\begin{array}{l}\text { Level IV studies or extrapolations from } \\
\text { level II or III studies }\end{array}$ & Weak against \\
\hline Strength D & - & $\begin{array}{l}\text { Level V evidence or troubling } \\
\text { inconsistent or inconclusive studies of } \\
\text { any level }\end{array}$ & Strong against \\
\hline Panel consensus & - & $\begin{array}{l}\text { Opinion supported by entire Canadian } \\
\text { Fibromyalgia Guidelines Committee }\end{array}$ & - \\
\hline
\end{tabular}

Abbreviations: $\mathrm{SR}=$ systematic review, $\mathrm{RCT}=$ Randomised Control trial . 
The 2012 Canadian guideline [7,8] was developed by the Canadian Fibromyalgia Guideline Committee (CFGC), comprising of 12 members of relevant healthcare professionals, a patient representative, an external international expert and a research coordinator. The literature search covered a 20-year period (1990-2010) and a broad scope of evidence was considered not limited to randomised controlled trials (RCTs). The recommendations were then submitted to the 35 members who form the National Fibromyalgia Guideline Advisory Panel. Recommendations were graded according to the classification system of the Oxford Centre for Evidence Based Medicine [9]. The primary recommendation of these guidelines indicates a paradigm shift in terms of the diagnosis and management of fibromyalgia, with an emphasis on the delivery of care in the community. Greater patient involvement in terms of educations and self-management was also highlighted. The guideline acknowledges that pharmacological therapy, even at best, is only modestly effective, but that regular physical activity should be considered the cornerstone of treatment, with the highest level of recommendation.

The German guideline [10] was developed by the Association of the Scientific Medical Societies in Germany (AWMF) which is a 12-member committee comprising of representatives from 10 scientific societies and two patient self-help organizations. The process was initiated and coordinated by the German Interdisciplinary Association of Pain Therapy (DIVS). The recommendations are based on a systematic review of the literature (all controlled studies, systematic reviews and meta-analysis) up to 31 December, 2010. In the AWMF guidelines, where no high-quality evidence was reported to be available, uncontrolled trials and case series were reviewed and expert opinion was sought. Level of evidence was based on the Oxford Centre for Evidence Based Medicine system [11], and the grading of the recommendations based on the German Programme for Disease Management guidelines [12] (Table 1). The recommendations are made based on the efficacy of the intervention, associated risks, patient preference and practicability/applicability (i.e., was the drug approved for therapy of FMS and/or its common comorbidities in German). The AWMF guideline highlights the importance of partnership with patients and also developing realistic aims of therapy based on informed-decision making, local availability, cost and patient presences. The summary recommendation is strongly in favor of physical activity treatment options, such as exercise and psychological therapies. Continuous pharmacological treatment is only recommended where the benefits are sustained.

The comparison of the categorisation of the evidence and recommendations of the three guidelines is listed in Table 1.

\section{Pharmaceutical Therapies}

Each of the three guidelines was interrogated for its source data, and the levels of evidence for each pharmaceutical agent/class evaluated based on the included articles. Unless stated, the guidelines used systematic review articles and meta-analysis as the basis of their recommendations, although the robustness of these reviews and the quality of the included studies was variable. The summaries of the article are included in Appendix A. The choice of pharmaceutical therapies in treating patient with FMS should be guided by the patient's clinical features, side effect profile, and response. FMS patients started on pharmaceutical therapies should be reviewed frequently and the dose titrated up based upon the patient's response. Where therapy has not demonstrated a positive effect, or where side effects are prominent, treatment should be discontinued.

\section{Amitriptyline}

Amitriptyline (AMT) is a tricyclic antidepressant known to inhibit both serotonin and noradrenalin reuptake, and has long been used for the management of neuropathic pain and FMS. The AWMF guidelines assessed 12 studies in their meta-analysis, whereas the Canadian guidelines examined only two systematic reviews, whilst EULAR examined five review articles (Table A1, Appendix A).

AMT has received a strong recommendation from AWMF (10-50 mg/daily), while the EUALR guidelines suggest only low dose may be beneficial, although with a high degree of consensus. The 
Canadian guidelines take a much more a general approach to AMT, and recommend that all categories of antidepressants, including SSRI and NSRI may be used for the treatment of FMS depending on the individual efficacy of the drug, physician's knowledge, patient's characteristics, and cost. Nishishinya et al. also concluded that AMT $25 \mathrm{mg}$ /day improved pain, sleep and fatigue at 6-8 weeks with no evidence for $50 \mathrm{mg} /$ day [13].

\section{Anticonvulsants}

Pregabalin (PGB) and Gabapentin (GBP) are both structurally similar to the neurotransmitter $\gamma$-aminobutyric acid (GABA), although neither drug has activity in GABA's neuronal system. Their analgesic effect is linked to their ability to bind to voltage-gated calcium channels in the central nervous system (CNS) [14]. An eight-week, double-blind, randomised clinical trial of 529 patients with FMS demonstrated the efficacy of PGB at different doses (300 mg, $450 \mathrm{mg}$ ), demonstrating a more than 50\% improvement in pain with PGB $450 \mathrm{mg} /$ day. Other domains including sleep quality, fatigue, and health related quality of life also showed improvement [15]. In a Cochrane review, a daily dose of $600 \mathrm{mg}$ produced no better outcome than $450 \mathrm{mg}$ /day for any outcome measures [16]. The recommendations across the guidelines with regards to the use of these drugs are somewhat variable; the CPS recommends using anticonvulsants with data derived from level 1 evidence (Table A2, Appendix A), while AWMF recommends using PGB (150 to $450 \mathrm{mg}$ /day) if treatment with AMT is not possible, and refrains from making any recommendations with regards to GBP. EULAR guideline analyses nine review articles on PGB $(n=1481$ to 3334$)$ and one clinical trial on gabapentin $(n=150)$. EULAR recommends use of PGB (weak for), and gabapentin for research purposes only.

Use of PGB and GBP may be limited by their side effect profile such as dizziness, somnolence, weight gain, peripheral oedema, and negative neurocognitive effects [17].

\section{Serotonin-Noradrenalin Reuptake Inhibitors (SNRI)}

Serotonin (5-HT) and noradrenalin have been implicated in the mediation of the descending pain inhibitory pathways [18], which have in turn been linked to the pathophysiology of FMS. Patients with FMS have been found to have decreased concentration of 5-HT and its precursor (tryptophan) in serum and cerebrospinal fluid [19]. Serotonin is implicated in psychiatric disorders such as depression and anxiety [20], and is theorized to have a role in pain threshold and stage 4 sleep [19].

Duloxetine (DLX) has a five-fold stronger effect on serotonin than on noradrenalin [21]. AWMF analyses five RCTs with 1157 participants, whilst EULAR uses eight systematic reviews with 443 to 2249 participants (Table A5, Appendix A). AWMF recommends DLX (60 mg/day) for patients with comorbid depressive disorder, with or without general anxiety disorders. This recommendation is also endorsed in the CPS and EULAR guidelines. DLX dose and length of therapy is guided by patient response and side effect profile. However, DLX 20-30 mg/day has not shown to be effective, and no difference was found between $60 \mathrm{mg}$ /day compared to $120 \mathrm{mg} /$ day [22].

Milnacipran (MLN) has three-fold stronger effect on noradrenalin than serotonin. It is recommended by EULAR (seven systematic reviews) and has been shown to be effective [21,23-26], though DLX was found to be superior to MLN in reducing pain and sleep problems [27]. AWMF guidelines do not recommend the use of MLN. This is based on low quality evidence, with low acceptance amongst patients and high risks of side effects. There is not enough available evidence with regards to the use of other agents such as venlafaxine in the management of FM.

\section{Selective Serotonin Reuptake Inhibitors}

A recent Cochrane review concluded that there was no unbiased evidence with regards to superiority of SSRIs to placebo in treating the key symptoms of fibromyalgia (pain, fatigue and sleep problems), however they might be considered for treating depression in this group of patients [28]. National and international guidelines are mixed with regards to their recommendations on SSRIs. EULAR guidelines are derived from seven systematic reviews, whilst AWMF uses eight RCTs in their 
meta-analysis (Table A4, Appendix A). EULAR does not recommend their use, whereas the Canadian and AWMF guidelines do recommend their use. Fluoxetine $20-40 \mathrm{mg}$ /day or paroxetine $20-40 \mathrm{mg}$ /day can be considered for a limited period of time in comorbid depressive/anxiety disorders $[29,30]$. Citalopram was ineffective in management of FMS in a small RCT of 40 patients [31].

\section{Opioids}

Use of strong opioids has been discouraged in the treatment of FMS. There is a deficit in opioid mediated descending anti-nociceptive activity in patients with FMS, with increased level of endogenous opioids in the CSF [32] and decreased central $\mu$-opioid receptor availability [33], which may explain the lack of effectiveness of exogenous opioids in this group of patients.

Tramadol is a weak opioid with combined $\mu$-receptor agonist and 5-HT and norepinephrine reuptake inhibition activity [34]. It is this latter action that is possibly the key in its efficacy in FMS compared to other opioids. The efficacy of tramadol in FMS has been studied in number of trials [35-38], although the long-term efficacy and the optimal dose of tramadol have not been addressed by the clinical trials. EULAR guidelines use two meta-analysis, Canadian guidelines 2RCTs whilst AWMF uses only one RCT (Table A6, Appendix A). Tramadol is recommended by EULAR and the Canadian guidelines, whereas AWMF refrain from making any recommendations on the basis of lack of data.

\section{Cyclobenzaprine}

Cyclobenzaprine is a centrally acting muscle relaxant which is structurally related to TCA, and which was first developed as an antipsychotic therapy [39]. The EULAR guideline recommends the use of cyclobenzaprine (weak for, 75\% agreement) based on one systematic review involving 312 patients (Table A3, Appendix A) [40]. Overall, patients treated with cyclobenzaprine were three times more likely to report overall improvement but there was no improvement on fatigue. In total, $85 \%$ of patients experienced side effects and only $71 \%$ completed the studies. The AWMF guidelines do not recommend the use of this medication on the basis of lack of license for its use, and risk of side effects (confusion, skin lesions, liver toxicity).

\section{Cannabinoids}

Cannabinoid molecules have been shown to have analgesic properties as well as sleep promoting affects [41], hence there has been increasing interest in their use in pain management. The endogenous cannabinoids and their receptors have been localized to multiple levels of nervous system (both peripheral and central) [42], and have an acknowledged role in helping to regulate neural process associated with pain perceptions, mood, appetite and memory [43]. The Canadian guidelines recommend the use of pharmacological cannabinoids, particularly in the setting of sleep disturbance, although it has not received any recommendations by AWMF and EULAR. There is also concern with regards the risk of abuse [44], there is a general need for further research into their use.

\section{Analgesic Treatments (Non-Steroidal Anti-Inflammatory (NSIADs) and Acetaminophen)}

Use of NSIADs for the management of FMS symptoms are not recommended by EULAR and AWMF. These recommendations come from a small number of studies (Table A7 Appendix A). A recent Cochrane review on NSAIDs in FMS also came to the same conclusion [45]. However, the Canadian guidelines, though not directly supporting their use in FMS, recommend using this group of drugs with the lowest possible dose for the shortest possible times in concurrent conditions such as osteoarthritis. Acetaminophen's actions, such as modulating the endogenous cannabinoid system [46], and serotonin receptor agonist [47], may be beneficial in FMS. There is no direct evidence with regards to the use of acetaminophen in FMS though it has been used in combination with tramadol [35].

Table 2 provides the list of medications that are not recommended for use in FMS, and which are not discussed in this paper. 
Table 2. Medications not recommended for treatment of fibromyalgia. Where no recommendation for/against is offered, a grey box is used. LE: level of evidence.

\begin{tabular}{|c|c|c|c|}
\hline Drug & AWMF (LE) & EULAR & Canadian Guideline \\
\hline Acetaminophen & No positive or negative recommendation & & May be used in some patients (level 5) \\
\hline Antiviral Drugs & Strong negative $(2 \mathrm{~b})$ & & \\
\hline Anxiolytics & Strong negative $(2 b)$ & & \\
\hline Dopamine agonists & Strong negative (2)a & & \\
\hline Flupirtine & Negative (4) & & \\
\hline Hormones (Growth hormone, Glucocorticoids, Calcitonin, oestrogen) & Strong negative (3a) & Strong against & \\
\hline Hypnotics & Strong negative (3a) & & \\
\hline Interferon & Strong negative (3a) & & \\
\hline Ketamine & Strong negative $(4 a)$ & & \\
\hline Local anaesthetic & Strong negative (3a) & & \\
\hline Monoamine oxidase inhibitor & Negative (2a) & Weak against & \\
\hline Sodium Oxybate & Strong negative (3a) & Strong against & \\
\hline Neuroleptics & Strong negative $(3 a)$ & & \\
\hline Strong opioids & Strong negative $(4 \mathrm{~b})$ & Strong against (5) & Discouraged Level 5, grade D \\
\hline Serotonin Receptor Antagonist & Strong negative (3a) & & \\
\hline
\end{tabular}




\section{Discussion}

Discordance between the guidelines on recommendations for pharmacological treatments for of FMS is primarily due to lack of high-quality randomized control trials in FMS, hence the guidelines rely on lower-quality evidence and expert consensus. Perhaps most tellingly, the latest guidelines all recommend non-pharmacological therapies, such as exercise, with a greater level of confidence than pharmacological agents, perhaps in part due to low risk of side effects and the generic health benefit of exercise. Despite this, the pharmacological treatment of FMS has an acknowledged role, especially where symptoms of or a concurrent diagnosis of depression is prominent.

One potential source of divergence in the guidelines in in the difference between their respective committees. The EULAR committee is formed of experts from 12 European countries with different health care systems, populations needs, and to some degree availability of therapies. EULAR also focuses mainly on systematic reviews (with or without meta-analysis), which provide the highest level of evidence, although narrowing the breadth of the guidance. AWMF, however, uses clinical trials as well as the systematic reviews, thus potentially capturing a greater number of admittedly lower quality studies. The Canadian guidelines uses original studies, systematic reviews, and evidence-based guidelines, and was perhaps the broadest approach to evidence gathering, although the number of included studies was actually less than that of the AWMF guidelines.

Further to the methodological differences between the guidelines, the divergence of the guidelines is also compounded by the variability with regards to the licensing of drugs in FMS. In the US, the FDA approved medications for FMS include duloxetine, MLN, and PGB, whereas opioids are not approved for treatment of fibromyalgia. Only PGB and duloxetine had Health Canada approval for management of FMS, and the use of other drugs is effectively "off-label" (use the guidance ref on line). In Germany, no drug is specifically licensed for FMS. Each of these factors may influence the prescribing patterns of clinicians managing patients included in the contributory data, and in the future of clinical practice.

Additionally, the guidelines do not offer information based on the outcomes for each of the six OMERACT core domains (pain, sleep disturbance, fatigue, affective symptoms, functional deficit, and cognitive impairment) [48], which would have allowed direct comparison of the evidence between studies and pertaining to individual disease components. This analysis would in turn help clinicians provide individualized care for patients exhibiting differing manifestations of FMS.

The guidelines are however all in agreement that therapy should be tailored to the individual needs of the patient, and that non-pharmacological therapy should be encouraged in the first instance. This is again reiterated in the Canadian guidelines, where a shift to community based care (general practice) is emphasized, also highlighting the fact that the ACR diagnosis guidelines (1990 and 2010) were mainly designed for research purposes.

EULAR recommends using DLX, PGB, or tramadol (in combination with paracetamol) in severe pain, and that AMT, cyclobenzaprine, or PGB should be considered at night for sleep problems. This is in contrast to the Canadian guidelines, which make only general recommendations on groups of drugs, rather than focusing on a specific agent. Despite the guidelines stating level 1 evidence for antidepressant medications (TCA, SSRI, and SNRI) and anticonvulsants, it does not provide enough information to the prescriber with the regards to the choice of medication, optimum dosage, and the duration of therapy.

The AWMF (2012) guidelines recommend AMT as a first-line pharmacological treatment, with duloxetine as a second-line treatment in patients who cannot tolerate AMT and have concurrent depressive disorder. The AWMF guidelines are also more explicit with regards the use and duration of the pharmacological therapy; recommending a trial treatment of at least 6 months, after which, if no effect is observed, the therapy should be stopped. This is based on the maximum duration of RCT study with AMT, Duloxetine and Pregabalin being 6 months [10].

Canadian 2012 guidelines, as well as shifting the diagnosis and management of FMS to the primary care, support the use of combination of non-pharmacological and drug therapy in fibromyalgia. 
However, their recommendation with regards to the pharmacological therapy is vague and depends heavily on the expertise of the reader.

Despite advances in the understanding of the pathophysiology of FMS, the pharmacological management has remained complex and poorly evidenced. What is clear is that an individualized approach to patient care is imperative, and that pharmacological therapy should be considered as an adjunct to non-pharmacological intervention. Where medication is deemed necessary, it should be targeted specifically towards the specific symptoms of the FMS in the individual patient, and if no improvement is observed after a reasonable trial period, should be discontinued. It is also important to note the risks of side effects of these medications, which may add to the complexity of the picture (Table 3). There is currently no evidence to support the use of multiple therapies for FMS, although this is commonly seen in clinical practice. Concerns regarding licensing should be addressed by regulatory bodies, especially where there are concerns regarding the widespread use of "off-license" therapies.

Table 3. Contraindications, warning and precautions with regards to the most commonly used drugs in fibromyalgia syndrome (FMS) as per summary of product characteristic (SPC).

\begin{tabular}{|c|c|c|c|}
\hline Drug & Contraindications & Warning and Precautions & Last Update \\
\hline Amitriptyline & $\begin{array}{c}\text { Prior Hypersensitivity } \\
\text { Concomitant use of MAOI } \\
\text { Acute recovery phase following } \\
\text { myocardial infarction } \\
\text { Mania } \\
\text { Sever liver disease } \\
\text { Congestive heart failure }\end{array}$ & $\begin{array}{c}\text { Suicidality } \\
\text { Hyponatraemia } \\
\text { QT interval prolongation on ECG } \\
\text { Blood dyscrasias }\end{array}$ & 5 December 2016 \\
\hline Duloxetine & $\begin{array}{l}\text { Serotonin syndrome and MAOIs. } \\
\text { Concomitant use of irreversible } \\
\text { MOAi, fluvoxamine, ciprofloxacin or } \\
\text { enoxacin } \\
\text { Liver disease resulting in hepatic } \\
\text { impairment } \\
\text { Severe renal impairment }\end{array}$ & $\begin{array}{c}\text { Mania and seizures } \\
\text { Mydriasis } \\
\text { Hypertension } \\
\text { Renal impairment } \\
\text { Serotonin syndrome } \\
\text { Suicide } \\
\text { Diabetic peripheral neuropathic pain } \\
\text { Hyponatraemia }\end{array}$ & 8 February 2008 \\
\hline Pregabalin & $\begin{array}{l}\text { Known hypersensitivity to pregabalin } \\
\text { (PGB) or any of its components }\end{array}$ & $\begin{array}{c}\text {-Hypersensitivity reaction } \\
\text {-Dizziness, somnolence, loss of } \\
\text { consciousness } \\
\text {-Vision-related effects } \\
\text {-Increase risk of suicidal thoughts and } \\
\text { behaviours } \\
\text {-Encephalopathy } \\
\text { Reduced lower gastrointestinal tract } \\
\text { function }\end{array}$ & 14 November 2016 \\
\hline $\begin{array}{l}\text { Tramadol } \\
\text { Hydrochloride }\end{array}$ & $\begin{array}{c}\text { Hypersensitivity to tramadol or other } \\
\text { opioids } \\
\text { Severe hepatic/renal impairment } \\
\text { MOA or within } 2 \text { weeks of their } \\
\text { withdrawal }\end{array}$ & $\begin{array}{l}\text { Withdrawal symptoms } \\
\text { Dependence and abuse } \\
\text { Convulsive disorders }\end{array}$ & 22 September 2015 \\
\hline Milnacipran & $\begin{array}{l}\text { HypersensitivityConcomitant use to } \\
\text { MAOI } \\
\text { Liver disease resulting in hepatic } \\
\text { impairment } \\
\text { Uncontrolled hypertensionSevere } \\
\text { renal impairment }\end{array}$ & As per Duloxetine & 8 February 2017 \\
\hline SSRI (Fluoxetine) & $\begin{array}{l}\text { Concomitant of metoprolol and } \\
\text { irreversible non-selective MAO, } \\
\text { hypersensitivity to the active } \\
\text { substance }\end{array}$ & $\begin{array}{c}\text { Suicidality } \\
\text { Rash and allergic reaction } \\
\text { Seizures } \\
\text { Mania } \\
\text { Hepatic/renal function } \\
\text { Prolonged QT }\end{array}$ & 22 December 2016 \\
\hline
\end{tabular}

Conflicts of Interest: The authors declare no conflict of interest. 


\section{Appendix A}

List of evidence used to formulate the guidelines.

Table A1. Amitriptyline (AMT)

\begin{tabular}{|c|c|c|c|c|}
\hline Guidelines & Type of Studies & Studies & Comment & Recommendation \\
\hline \multirow{5}{*}{ EULAR } & \multirow{5}{*}{$\begin{array}{l}5 \text { Reviews ( } 5-13 \text { clinical } \\
\text { trials, } 322 \text { to } 919 \\
\text { participants) }\end{array}$} & Häuser, W. et al. 2011 [49] & $\begin{array}{l}\text { Systematic review with meta-analysis including } 5 \text { trials }(n=612) \text {. } \\
\text { AMT cannot be regarded as the gold standard of FMS therapy with } \\
\text { antidepressants because of the methodological limitations of its trials. }\end{array}$ & \multirow{5}{*}{$\begin{array}{l}\text { AMT Weak for, at low dose } \\
\quad(100 \% \text { agreement })\end{array}$} \\
\hline & & Nishishinya, B. et al. 2008 [13] & $\begin{array}{l}\text { Systematic review including } 5 \text { RCT s }(n=615) \text {. Definitive clinical } \\
\text { recommendation regarding the efficacy of AMT for FM could not be } \\
\text { made. There is some evidence to support short-term efficacy of AMT } \\
25 \mathrm{mg} / \text { day. However, there is no evidence to support higher dose or } \\
\text { for period more than } 8 \text { weeks. }\end{array}$ & \\
\hline & & Üceyler, N. et al. 2008 [50] & $\begin{array}{l}\text { Systematic review including } 13 \text { RCTs }(n=850) \text {. AMT } 25-50 \mathrm{mg} / \text { day } \\
\text { reduced pain, fatigue and depression in patients with FMS with } \\
\text { improvement in sleep and quality of life. }\end{array}$ & \\
\hline & & Moore, R.A. et al. 2012 [51] & $\begin{array}{c}\text { Cochrane review including } 7 \text { RCTs }(n=548) \text {. There was some } \\
\text { evidence that amitriptyline at } 25 \text { or } 50 \mathrm{mg} \text { daily was better } \\
\text { than placebo. }\end{array}$ & \\
\hline & & Perrot, S. et al. 2014 [52] & $\begin{array}{l}\text { Meta-analysis, including } 5 \text { studies }(n=500) \text {. AMT was effective at } \\
\text { reducing pain, sleep disturbance and improving fatigue. }\end{array}$ & \\
\hline \multirow{6}{*}{ AWMF } & \multirow{6}{*}{$\begin{array}{l}18 \text { systematic reviews } \\
\text { were analysed overall, } \\
\quad(n=1014) \text { with } 14 \\
\text { studies on AMT. } 12 \\
\text { studies were included in } \\
\text { the meta-analysis which } \\
\text { are listed in this table. }\end{array}$} & Capaci, K. et al. 2002 [53] & $\begin{array}{l}\text { Randomised trial, paroxetine ( } 20-40 \mathrm{mg} \text { / daily) vs. AMT } 10-20 \mathrm{mg} \\
\text { daily. AMT works better than paroxetine. }\end{array}$ & \multirow{6}{*}{$\begin{array}{l}\text { AMT } 10-50 \mathrm{mg} / \text { day should be } \\
\text { used for a limited period of time. } \\
\text { Level of evidence } 2 \mathrm{a} . \\
\text { Strong consensus. }\end{array}$} \\
\hline & & Carette, S. et al. 1986 [54] & $\begin{array}{l}\text { Double blind placebo control trial, comparing AMT } 50 \mathrm{mg} / \text { day to } \\
\text { placebo. Improvement in sleep and physician global assessment in } \\
\text { the MT group. }\end{array}$ & \\
\hline & & Carette, S. et al. 1994 [55] & $\begin{array}{l}\text { Randomised double blind trial comparing AMT, cyclobenzaprine } \\
\text { and placebo confirmed short-term efficacy of the two drugs in FMS. }\end{array}$ & \\
\hline & & Carette, S. et al. 1995 [56] & $\begin{array}{l}\text { Double blind, cross-over trial of AMT }(25 \mathrm{mg}) \text { vs. placebo. Alpha } \\
\text { NREM abnormality exists in a small group of patients with FM and is } \\
\text { not corrected by AMT. }\end{array}$ & \\
\hline & & Caruso, I. et al. 1987 [57] & $\begin{array}{c}\text { Double blind study of dothiepin versus placebo which showed } \\
\text { improvement in the treatment arm. }\end{array}$ & \\
\hline & & Garcia, J. et al. 2006 [58] & $\begin{array}{l}\text { Randomised controlled trial showed that CBT was superior to } \\
\text { pharmacolical therapy (cyclobenzaprine) in FMS. }\end{array}$ & \\
\hline
\end{tabular}


Table A1. Cont.

\begin{tabular}{|c|c|c|c|c|}
\hline Guidelines & Type of Studies & Studies & Comment & Recommendation \\
\hline \multirow{7}{*}{ AWMF } & \multirow{7}{*}{$\begin{array}{l}18 \text { systematic reviews } \\
\text { were analysed overall, } \\
\quad(n=1014) \text { with } 14 \\
\text { studies on AMT. } 12 \\
\text { studies were included in } \\
\text { the meta-analysis which } \\
\text { are listed in this table. }\end{array}$} & Ginsberg, F. et al. 1996 [59] & $\begin{array}{l}\text { Randomised placebo-controlled trial on use of sustained released } \\
\text { AMT ( } 25 \mathrm{mg}) \text { showed potential benefits in FM. }\end{array}$ & \multirow{7}{*}{$\begin{array}{l}\text { AMT } 10-50 \mathrm{mg} / \text { day should be } \\
\text { used for a limited period of time } \\
\text { Level of evidence } 2 \mathrm{a} . \\
\text { Strong consensus. }\end{array}$} \\
\hline & & Goldenberg, D.L. et al. 1986 [60] & $\begin{array}{l}\text { Randomised controlled trial of AMT }(25 \mathrm{mg}) \text { and Naproxen, which } \\
\text { showed AMT was associated with significant improvement in } \\
\text { all outcomes. }\end{array}$ & \\
\hline & & Goldenberg, D. et al. 1996 [29] & $\begin{array}{l}\text { Randomised double blind cross-over trial of AMT }(25 \mathrm{mg}) \text { and } \\
\text { Fluoxetine }(20 \mathrm{mg}) \text { showed both are effective and they work better in } \\
\text { combination in FMS. }\end{array}$ & \\
\hline & & Hannonen, P. et al. 1998 [61] & $\begin{array}{l}\text { Randomised double blind placebo controlled study on AMT and } \\
\text { moclobemide showed that AMT was effective in FMS (general health, } \\
\text { pain and sleep quality). }\end{array}$ & \\
\hline & & Heymann, R.E. et al. 2001 [62] & $\begin{array}{l}\text { Randomised double blind control study on AMT }(25 \mathrm{mg}) \text {, } \\
\text { nortriptyline }(25 \mathrm{mg}) \text { and placebo. All three groups improved. Only } \\
\text { the patients' subjective global assessment differed between the } \\
\text { AMT group. }\end{array}$ & \\
\hline & & Kempenaers, C. et al. 1994 [63] & $\begin{array}{l}\text { Randomised double blind trial comparing SER } 282 \text { with AMT } \\
(50 \mathrm{mg}) \text { or placebo. AMT did not have any effect on sleep. }\end{array}$ & \\
\hline & & Scudds, R.A. et al. 1989 [64] & $\begin{array}{l}\text { Randomised double blind cross-over study on AMT ( } 25 \mathrm{mg}-50 \mathrm{mg}) \\
\text { vs. placebo. AMT was associated with significant improvement. }\end{array}$ & \\
\hline \multirow[t]{2}{*}{ CANADA } & \multirow[t]{2}{*}{2 systematic reviews } & Hauser, W. et al. 2009 [65] & $\begin{array}{l}7 \text { studies, } n=446 \text {, Strong evidence for the efficacy of the } \\
\text { amitriptyline in reducing pain, fatigue and sleep disturbances It } \\
\text { concludes that short-term usage of AMT can be considered for } \\
\text { treatment of pain and sleep disturbance in FMS. }\end{array}$ & TCA may be used in FMS. \\
\hline & & Üceyler, N. et al. 2008 [50] & As Per EULAR & Level 1, Grade A \\
\hline
\end{tabular}


Table A2. Anticonvulsants.

\begin{tabular}{|c|c|c|c|c|}
\hline Guideline & No. Reviews & Reviews & Comment & Recommendation \\
\hline \multirow{9}{*}{ EULAR } & \multirow{9}{*}{$\begin{array}{l}\text { PGB } 9 \text { reviews (1481 to } 3334 \\
\text { participants) Gabapentin } 1 \\
\text { clinial trial } 150 \\
\text { participants—not relevant }\end{array}$} & Choy, E. et al. 2011 [66] & $\begin{array}{l}\text { Systematic review and mixed treatment comparison. } 5 \text { RCTs on Pregabalin } \\
\text { confirmed therapeutic efficacy (pain, fibromyalgia impact questionnaire } \\
\text { scores) for PGB. }\end{array}$ & \multirow{9}{*}{$\begin{array}{l}\text { PGB weak for }(94 \% \text { agreement } \\
\text { Gabapentin-research only } \\
\text { (100\% agreement). }\end{array}$} \\
\hline & & Tzellos, T.G. et al. 2010 [67] & $\begin{array}{l}\text { Systematic review and meta-analysis on gabapentin and PGB. } 4 \text { RCTs } \\
(n=2040) \text { PGB at the dose of } 450 \mathrm{mg} \text { is most likely effective in treating FM, the } \\
\text { data on gabapentin is limited. Adverse events are not negligible }\end{array}$ & \\
\hline & & Üceyler, N. et al. 2013 [68] & $\begin{array}{l}\text { Cochrane review PGB demonstrates a small benefit in reducing pain and } \\
\text { sleeping problems with no substantial effect on fatigue compared to placebo. } \\
\text { Study drop-out rates due to adverse events were higher with PGB use } \\
\text { compared with placebo. }\end{array}$ & \\
\hline & & Siler, A.C. et al. 2011 [69] & $\begin{array}{c}\text { Systematic review, } 5 \text { RCTs on PGB and } 1 \text { on gabapentin. PGB and gabapentin } \\
\text { are modestly effective in treatment of fibromyalgia though their long-term } \\
\text { safely and efficacy remains unknown. }\end{array}$ & \\
\hline & & Roskell, N.S. et al. 2011 [70] & $\begin{array}{l}\text { Meta-analysis, PGB } 3 \text { RCTs, Gabapentin } 1 \text { RCT. A } 30 \% \text { pain reduction was } \\
\text { observed in patients treated with gabapentin and PGB ( } 300 \mathrm{mg} \text { and } 450 \mathrm{mg} \text { ). } \\
\text { There was also significant risk of discontinuation due to adverse events. }\end{array}$ & \\
\hline & & Perrot, S. et al. 2014 [52] & $\begin{array}{c}\text { Meta-analysis, including } 2 \text { studies on PGB }(n=1497) \text { showing efficacy in pain } \\
\text { relief and improvement of function. }\end{array}$ & \\
\hline & & Häuser, W. et al. 2009 [17] & $\begin{array}{l}\text { Meta-analysis on treatment of FM with gabapentin and PGB. There was strong } \\
\text { evidence for reduction of pain, improve sleep and quality of life but not for } \\
\text { depressive symptoms. }\end{array}$ & \\
\hline & & Moore, R.A. et al 2009 [16] & $\begin{array}{l}\text { Cochrane review, on PGB for acute and chronic pain. Pregabalin was effective } \\
\text { at doses of } 300 \mathrm{mg}, 450 \mathrm{mg} \text { and } 600 \mathrm{mg} \text { in treating of variety of pain conditions } \\
\text { including FMS (5 studies). }\end{array}$ & \\
\hline & & Häuser, W. et al. 2010 [21] & $\begin{array}{l}\text { Comparative efficacy and harms of DLX, MLN, in PGB in FMS. The three } \\
\text { drugs are superior to placebo except DLX for fatigue, MLN for sleep } \\
\text { disturbance and PGB for depressed mood. }\end{array}$ & \\
\hline
\end{tabular}


Table A2. Cont.

\begin{tabular}{|c|c|c|c|c|}
\hline Guideline & No. Reviews & Reviews & Comment & Recommendation \\
\hline \multirow{5}{*}{ AWMF } & \multirow{5}{*}{4 RCTS, $n=4132$} & Crofford, L.J. et al. 2005 [15] & $\begin{array}{l}\text { Multi-centre double blind RCT on } 529 \text { patients. PGB at } 450 \mathrm{mg} / \text { day was } \\
\text { efficacious for the treatment of FMS, reducing symptoms of pain, disturbed } \\
\text { sleep, and fatigue compared with placebo. PGB was well tolerated and } \\
\text { improved global measures and health-related quality of life }\end{array}$ & \multirow{5}{*}{$\begin{array}{c}\text { Treatment with PGB } \\
\text { (150-450 mg/day) can be } \\
\text { considered for a limited time } \\
\text { period, if treatment with AMT } \\
\text { is not possible. } \\
\text { Level of evidence } 1 \mathrm{a} \text {, open } \\
\text { recommendation. } \\
\text { Due to the limited data } \\
\text { available for gabapentin neithe } \\
\text { a positive nor a negative } \\
\text { recommendation is possible. } \\
\text { Strong consensus. }\end{array}$} \\
\hline & & Arnold, L.M. et al. 2008 [71] & $\begin{array}{l}\text { Randomised double blind placebo controlled trial of PGB } 300 \mathrm{mg}, 450 \mathrm{mg} \text { and } \\
600 \mathrm{mg} / \text { day showed that all three doses were efficacious for up to } 14 \text { weeks. }\end{array}$ & \\
\hline & & Mease, P.J. et al. 2008 [72] & $\begin{array}{l}\text { Randomised double blind placebo controlled trial on the use of PGB 300, 450, } \\
\text { and } 600 \mathrm{mg} \text { /day which was efficacious and safe in the treatment of pain in FM. }\end{array}$ & \\
\hline & & $\begin{array}{l}\text { Pfizer (not published at the time } \\
\text { the guidelines was written) }\end{array}$ & $\begin{array}{c}14 \text { week randomised, double blind placebo controlled trial of Pregabalin twice } \\
\text { daily in patients with FM. }\end{array}$ & \\
\hline & & Arnold, L.M. 2007 [73] & $\begin{array}{l}\text { Randomised double blind, placebo-controlled trial, Gabapentin is effective } \\
\text { and safe in FM. }\end{array}$ & \\
\hline \multirow{3}{*}{ Canada } & \multirow{3}{*}{3} & Holtedhal. 20106 reviews [74] & $\begin{array}{c}\text { (Article in Norwesian) review of } 6 \text { randomised double blind controlled trial. } \\
\text { Recommendations for PGB is based on rather weak evidence. Mean pain } \\
\text { reduction between } 9 \% \text { to } 15 \% \text {. }\end{array}$ & \multirow{3}{*}{$\begin{array}{l}\text { Treatment with anticonvulsant } \\
\text { medications should begin with } \\
\text { the lowest possible dose } \\
\text { followed by up titration. } \\
\text { Level 1, Grade A. }\end{array}$} \\
\hline & & Hauser, W. et al. 2009 [17] & $\begin{array}{l}\text { A meta-analysis of randomized controlled trials on treatment of fibromyalgia } \\
\text { syndrome with gabapentin and PGB (6 RCT, } 8733 \text { participants) showed both } \\
\text { drugs were associated wig small but significant pain reduction, improved } \\
\text { sleep function but did not significantly affect the level of depression. }\end{array}$ & \\
\hline & & Moore, RA. et al. 2009 [16] & As Per EULAR & \\
\hline
\end{tabular}


Table A3. Cyclopnezaprine.

\begin{tabular}{|c|c|c|c|c|}
\hline Guideline & No. of studies & Reviews & Comments & Recommendation \\
\hline EULAR & 1 review with 5 trials & Tofferi, J.K. et al. 2004 [40] & $\begin{array}{l}\text { Systematic review including } 5 \text { placebo-control trials }(n=312) \text {. The odds ratio } \\
\text { for global improvement was } 3.0(95 \% \text { CI 1.6-5.6) with no improvement in } \\
\text { fatigue or tender points in FM. }\end{array}$ & Weak for (75\% agreement). \\
\hline \multirow{4}{*}{ AWMF } & \multirow{4}{*}{$\begin{array}{l}\text { List of studies included in the } \\
\text { meta-analysis }\end{array}$} & Bennett, R.M. 1988 [75] & $\begin{array}{l}\text { Double blind control study, comparison of cyclobenzaprine and placebo } \\
\text { showed significant reduction in total tender points and fatigue. }\end{array}$ & \multirow{4}{*}{$\begin{array}{l}\text { Negative recommendation. } \\
\text { strong consensus. } \\
\text { Level of evidence } 2 \mathrm{a} \text {. }\end{array}$} \\
\hline & & Carette, S. et al. 1994 [55] & $\begin{array}{l}\text { Randomised double blind trial to compare relative efficacy and safety of AMT } \\
\text { and cyclobenzaprine. Confirm short-term efficacy and safety of both. }\end{array}$ & \\
\hline & & Hamaty, D. 1989 [76] & $\begin{array}{l}\text { Double blind, cross-over study on plasma endorphin, prostaglandin and } \\
\text { catecholamine profile of patients treated with cyclobenzaprine compared } \\
\text { to placebo. }\end{array}$ & \\
\hline & & Reynolds, M. 1991 [77] & $\begin{array}{c}\text { Double blind, placebo controlled cross-over design on the effects of } \\
\text { cyclobenzaprine showed improvement in fatigue and total sleep with no } \\
\text { benefit on pain. }\end{array}$ & \\
\hline
\end{tabular}

Table A4. SSRI.

\begin{tabular}{|c|c|c|c|c|}
\hline Guideline & No. of Studies & Articles & Comment & Recommendation \\
\hline \multirow{7}{*}{ EULAR } & \multirow{7}{*}{$\begin{array}{l}7 \text { systematic reviews, } 3 \text { to } 11 \\
\text { trials and up to } 521 \text { patients }\end{array}$} & Hauser, W. et al. 2012 [78] & $\begin{array}{l}\text { Systematic review and meta-analysis including } 18 \text { RCTs on TCA, SSRI, SNRI and } \\
\text { MAOI ( } n=1427) \text {, concluded that antidepressant medications are associated with } \\
\text { improvement in pain, depression, fatigue, sleep disturbance and health related QOL } \\
\text { in FM. }\end{array}$ & \multirow{7}{*}{ Weak against $(94 \%)$} \\
\hline & & Üçeyler, N. et al. 2008 [50] & $\begin{array}{l}\text { Systematic review including } 26 \text { trials; AMT (13 RCTs), SSRIs ( } 2 \text { RCTs) and one on } \\
\text { paroxetine. The SSRIs fluoxetine ( } 20-40 \mathrm{mg} / \text { day), sertraline ( } 50 \mathrm{mg} / \text { day), and } \\
\text { paroxetine ( } 20 \mathrm{mg} / \text { day) reduce pain and depressiveness and improve sleep and } \\
\text { quality of life. Citalopram ( } 20-40 \mathrm{mg} / \text { day) is not superior to placebo. }\end{array}$ & \\
\hline & & Häuser, W. et al. 2009 [65] & $\begin{array}{l}\text { A meta-analysis on treatment of FMS with antidepressants, overall antidepressant are } \\
\text { effective in FMS but the effect size of SSRIs was small. }\end{array}$ & \\
\hline & & Perrot, S. et al. 2014 [52] & $\begin{array}{l}\text { Meta-analysis examining } 6 \text { core symptoms. Citalopram did not show any significant } \\
\text { benefit on pain, fatigue or effective symptoms. Fluoxetine might be beneficial at high } \\
\text { doses }(80 \mathrm{mg}) .\end{array}$ & \\
\hline & & Choy, E. et al. 2011 [66] & $\begin{array}{l}\text { Systematic review and mixed treatment comparison including paroxetine and } \\
\text { citalopram. Meta-analysis found no evidence of their superiority over placebo. }\end{array}$ & \\
\hline & & Jung, A.C. et al. 1997 [79] & $\begin{array}{l}\text { Systematic review of RCTs on SSRIs ( } 3 \text { studies on FMS). SSRIs appear to be beneficial } \\
\text { for mixed chronic pain, however it is unclear if SSRIs are beneficial for FMS. }\end{array}$ & \\
\hline & & Arnold, L.M. et al. 2000 [80] & $\begin{array}{l}\text { Meta-analysis and review of antidepressants treatment of fibromyalgia including } \\
\text { citalopram and fluoxetine did not show significant difference with placebo however } \\
\text { only } 2 \text { trials were included for analysis. }\end{array}$ & \\
\hline
\end{tabular}


Table A4. Cont.

\begin{tabular}{|c|c|c|c|c|}
\hline Guideline & No. of Studies & Articles & Comment & Recommendation \\
\hline \multirow{8}{*}{ AWMF } & \multirow{8}{*}{$\begin{array}{l}\text { Only articles used for } \\
\text { met-analysis are included in } \\
\text { this table }\end{array}$} & Arnold, L.M. et al 2002 [81] & $\begin{array}{c}\text { Randomised, double blind placebo-control trial, on }(n=66) \text {, fluoxetine was found to } \\
\text { be effective on most outcome measures and generally well tolerated in women } \\
\text { with fibromyalgia }\end{array}$ & \multirow{8}{*}{$\begin{array}{c}\text { Serotonin reuptake } \\
\text { inhibitors (SSRI; fluoxetine } \\
20-40 \mathrm{mg} / \text { day. } \\
\text { paroxetine: } 20-40 \mathrm{mg} / \text { day) } \\
\text { can be considered for a } \\
\text { limited time period in } \\
\text { patients with co- morbid } \\
\text { depressive disorder and } \\
\text { anxiety disorder. EL 2a, } \\
\text { open recommendation, } \\
\text { consensus. }\end{array}$} \\
\hline & & Goldenberg, D. et al. 1996 [29] & $\begin{array}{l}\text { Randomised double blind cross-over study, }(n=19) \text { AMT } 25 \mathrm{mg} \text { and Fluoxetine } \\
20 \mathrm{mg} \text {. Both drugs are effective in FM and work better in combination. }\end{array}$ & \\
\hline & & Wolf, F. et al. 1994 [30] & Double blind placebo controlled trial, $n=42$, fluoxetine $20 \mathrm{mg}$ did not improve FM. & \\
\hline & & Nørregaard, J. et al. 1995 [82] & Double blind control trial, $(n=22)$ citalopram $20-40 \mathrm{mg}$. No benefit reported & \\
\hline & & Sencan, S. et al. 2004 [83] & $\begin{array}{c}\text { Randomised control study, }(n=60) \text { paroxetine } 20 \mathrm{mg} \text { vs. aerobic exercise. Both } \\
\text { modalities improve pain compared to placebo with no significant difference between } \\
\text { the two interventions. }\end{array}$ & \\
\hline & & Anderberg, U.M. et al. 2000 [31] & $\begin{array}{l}\text { Randomised, double blind }(n=40) \text { placebo-control trial. Citalopram } 20-40 \mathrm{mg} \text {. No } \\
\text { significant change was found in the global judgment of improvement. }\end{array}$ & \\
\hline & & Patkar, A.A. et al. 2007 [84] & $\begin{array}{l}\text { Randomised double blind placebo control trial }(n=116) \text { on paroxetine }(12.5-62.5 \mathrm{mg}) \\
\text { showed that paroxetine improve overall symptomology in FMS. }\end{array}$ & \\
\hline & & Distler et al, 2010 [85] & $\begin{array}{l}\text { Randomised double blind, placebo control parallel group to investigate the efficacy } \\
\text { and safety of controlled release ropinirole (1-24 mg) }\end{array}$ & \\
\hline \multirow{2}{*}{ Canadian } & \multirow{2}{*}{ Reviews } & Üceyler, N. et al. 2008 [50] & As per EULAR & \multirow{2}{*}{$\begin{array}{c}\text { All categories of } \\
\text { antidepressants including } \\
\text { SSRI may be used (level 1, } \\
\text { grade A). }\end{array}$} \\
\hline & & Hauser, W. et al. 2009 [86] & Meta-analysis (as per EULAR) & \\
\hline
\end{tabular}


Table A5. Norepinephrine-Selective Reuptake Inhibitors (NSRI).

\begin{tabular}{|c|c|c|c|c|}
\hline Guideline & No. of Studies & Articles & Comment & Recommendation \\
\hline \multirow{10}{*}{ EULAR } & \multirow{10}{*}{$\begin{array}{l}\text { DLX } 8 \text { systematic reviews } \\
\text { including } 2-6 \text { trials, with } 443 \\
\text { to } 2249 \text { participants } \\
\text { Milnacipran } 7 \text { reviews, } 1-5 \\
\text { trials, } 125-4118 \text { participants }\end{array}$} & Häuser, W. et al. 2011 [49] & $\begin{array}{l}\text { Meta-analysis, ten AMT }(n=612) \text {, four DLX }(n=1411) \text { and five MLN }(n=4129) \\
\text { studies, showed that } 3 \text { drugs were superior to placebo except DLX for fatigue, MLN } \\
\text { for sleep and AMT for quality of life. AMT was superior to DLX and MLN for pain } \\
\text { reduction, sleep disturbance and quality fif life improvement. DLX was superior to } \\
\text { MLN in pain reduction, sleep disturbance and quality f life improvement. MLN was } \\
\text { superior to DLX in reducing fatigue. }\end{array}$ & \multirow{10}{*}{$\begin{array}{l}\text { Milnacipran and Duloxetine } \\
\text { weak for (100\% agreement) } \\
\text { Level of evidence } 1 \mathrm{~A} .\end{array}$} \\
\hline & & Perrot, S. et al. 2014 [52] & $\begin{array}{c}\text { Meta-analysis. DLX showed a statistically significant improvement in reducing pain, } \\
\text { sleep disturbance, fatigue, affective symptoms, functional deficit and cognitive } \\
\text { impairment. MLN improved pain but had no effect on sleep disturbance, fatigue, } \\
\text { affective symptoms and functional deficit. }\end{array}$ & \\
\hline & & Häuser, W. et al. 2010 [21] & $\begin{array}{l}\text { Review study on DLX, MLN and PGB (17 studies, } n=7739) \text {. The three drugs were } \\
\text { superior to placebo for all outcomes. DLX and PGB were superior to MLN in } \\
\text { reduction of pain and sleep disturbance, DLX was superior in reducing depressed } \\
\text { mood, MLN and PGB were superior in reducing fatigue. }\end{array}$ & \\
\hline & & Choy, E. et al. 2011 [66] & $\begin{array}{l}\text { A systematic review and mixed treatment comparison, confirmed the efficacy of PGB } \\
\text { and SNRIs in treatments of FMS. }\end{array}$ & \\
\hline & & Häuser, W. et al. 2013 [27] & $\begin{array}{l}\text { Cochrane review }(n=6038) .5 \text { studied on Duloxetine, } 5 \text { studies on MLN. Both drugs } \\
\text { provide a small benefit over placebo with no improvement in fatigue and quality of } \\
\text { life (QOL). }\end{array}$ & \\
\hline & & Sultan, A. et al. 2008 [87] & $\begin{array}{l}\text { Systematic review. DLX is equally effective for the treatment of peripheral diabetic } \\
\text { neuropathy and FM. Doses higher than } 60 \mathrm{mg} \text { do not provide additional pain relief, } \\
\text { but cause slightly more withdrawal due adverse effects. }\end{array}$ & \\
\hline & & Lunn, M.P. et al. 2014 [22] & $\begin{array}{c}\text { Cochrane review }(n=2249) \text {. Duloxetine in short-term ( } 12 \text { weeks) and long-term }(28 \\
\text { weeks) is more effective than placebo at reducing pain }(R R>30 \% \text { pain, RR } 1.38,95 \% \\
\text { CI } 1.22 \text { to } 1.56) \text {. There was no significant effect at } 20-30 \mathrm{mg} / \text { day and no difference } \\
\text { between } 60 \mathrm{mg} \text { and } 120 \mathrm{mg} / \text { day. }\end{array}$ & \\
\hline & & Ormseth, M.J. et al. 2010 [24] & $\begin{array}{l}\text { Review article. MLN has a demonstrated efficacy in managing global FMS symptoms } \\
\text { and pain at doses of } 100 \text { and } 200 \text { mg divided twice daily however it has numerous } \\
\text { side effects. }\end{array}$ & \\
\hline & & Lunn, M.P. et al. 2014 [22] & $\begin{array}{l}\text { Cochrane review on MLN for neuropathic pain in adults concluded that it was } \\
\text { effective for a minority in the treatment of pain due to FM. }\end{array}$ & \\
\hline & & Derry, S. et al. 2012 [23] & $\begin{array}{l}\text { Cochrane review on use of MLN for neuropathic pain }(n=4138) \text { concluded that MLN } \\
\text { is effective in a minority in treating pain in treating pain associated with FMS. }\end{array}$ & \\
\hline
\end{tabular}


Table A5. Cont.

\begin{tabular}{|c|c|c|c|c|}
\hline Guideline & No. of Studies & Articles & Comment & Recommendation \\
\hline \multirow{10}{*}{ AWMF } & \multirow{10}{*}{$\begin{array}{l}\text { No systematic reviews. } \\
\text { Duloxetine: } 5 \text { RCTs } n=1157 \\
\text { in the experimental group } \\
\text { Milnacipran }\end{array}$} & Arnold, L.M. et al. 2004 [88] & $\begin{array}{l}\text { Randomised double-blind, placebo controlled trial }(n=207) \text {. DLX }(120 \mathrm{mg} / \text { day }) \text { is } \\
\text { effective and safe in treating any symptoms of FM. } 120 \mathrm{mg} / \text { day resulted in more than } \\
50 \% \text { pain reduction in } 3 \text { months. }\end{array}$ & \multirow{10}{*}{$\begin{array}{l}\text { Treatment with DLX (60 mg) } \\
\text { can be considered for a } \\
\text { limited time period in } \\
\text { patients without comorbid } \\
\text { depressive disorders or } \\
\text { generalized anxiety } \\
\text { disorders, if treatment with } \\
\text { AMT is not possible. } \\
\text { MLN should not be used. } \\
\text { EL 1a, negative } \\
\text { recommendation, consensus. }\end{array}$} \\
\hline & & Arnold, L.M. et al. 2005 [89] & $\begin{array}{l}\text { Randomised double-blind placebo controlled trial. DLX } 60 \mathrm{~g}, 90 \mathrm{mg} \text { and } 120 \mathrm{mg} \text { were } \\
\text { effective in treatment of fibromyalgia with or without depressive symptoms. }\end{array}$ & \\
\hline & & Arnold , L.M. et al. 2010a [90] & $\begin{array}{l}\text { Randomised double blind placebo controlled trial, treatment with DLX 60, 90, } 120 \\
\text { mg/day was associated with pain reduction, better sleep and quality of life. }\end{array}$ & \\
\hline & & Chappell, A.S. 2009 [91] & $\begin{array}{c}\text { Randomised double blind placebo controlled trial. DLX } 60 / 120 \mathrm{mg} \text { failed to develop } \\
\text { significant improvement in the co-primary outcome measures (pain and patient } \\
\text { global impression of improvement). }\end{array}$ & \\
\hline & & Russell, I.J. et al. 2008 [92] & $\begin{array}{l}\text { Randomised double blind, placebo controlled trial }(n=1025) \text { on MLN }(100 \mathrm{mg} / \text { day vs. } \\
\text { Placebo). MLN improved pain, global status, fatigue and physical and mental } \\
\text { function. }\end{array}$ & \\
\hline & & Arnold, L.M. et al. (2010b) [93] & $\begin{array}{l}\text { Randomised double blind placebo control trial. Milnacipran administered at a dosage } \\
\text { of } 100 \mathrm{mg} \text { /day improved pain, global status, fatigue, and physical and mental } \\
\text { function in patients with fibromyalgia. }\end{array}$ & \\
\hline & & Branco, J.C. 2010 [94] & $\begin{array}{l}\text { Randomised double blind, placebo controlled, multicentre clinical trial }(n=884) \text {. } \\
\text { MLN } 200 \mathrm{mg} \text { was associated with significant improvement. }\end{array}$ & \\
\hline & & Clauw, D.J. et al. 2008 [26] & $\begin{array}{l}\text { A 15-week, multicentre, randomised, double-blind, placebo-controlled, multi-dose } \\
\text { trial }(n=2270) \text { of MLN } 100 \mathrm{~g}, 200 \mathrm{mg} \text { and placebo showed significant improvement in } \\
\text { both doses of MLN. }\end{array}$ & \\
\hline & & Mease, P.J. et al. 2009 [25] & $\begin{array}{l}\text { Randomised double blind placebo controlled trial, on the efficacy and safety of MLN } \\
\text { favored use of MLN in FM }(n=888) .\end{array}$ & \\
\hline & & Vitton, O. et al. 2004 [95] & $\begin{array}{l}\text { Double blind placebo-controlled trial ( } n=125) .75 \% \text { of treated patients reported } \\
\text { overall improvement compared to } 38 \% \text { in placebo group }(p<0.01) \text {. MLN may have } \\
\text { the potential of relieving not only pain but several other symptoms in FM. }\end{array}$ & \\
\hline \multirow[b]{2}{*}{ Canadian } & & Üceyler, N. et al. 2008 [50] & $\begin{array}{l}\text { Systematic review, } 2 \text { studies on DLX and } 1 \text { on Milnacipran. DLX } 60-120 \mathrm{mg} \text { and MLN } \\
25-500 \mathrm{mg} \text { /day reduce pain and depressive symptoms and improve sleep and quality } \\
\text { if life. }\end{array}$ & \multirow{2}{*}{$\begin{array}{l}\text { Level } 1, \text { Grade A } \\
\text { All categories of } \\
\text { antidepressants may be } \\
\text { used for treatment of pain } \\
\text { and other symptoms in } \\
\text { fibromyalgia. }\end{array}$} \\
\hline & & Hauser, W. et al. 2009 [65] & $\begin{array}{c}\text { Meta-analysis, } 3 \text { studies on DLX, } 1 \text { on MLN. Strong evidence for the efficacy of } \\
\text { Duloxetine and MLN in reducing pain (smd, }-0.36 ; 95 \% \text { CI, }-0.46 \text { to }-0.25 ; p<0.001 \text { ) } \\
\text { and sleep disturbance. Strong evidence for DLX in improving depressed mood and } \\
\text { quality of life. }\end{array}$ & \\
\hline
\end{tabular}


Table A6. Tramadol.

\begin{tabular}{cccc}
\hline Guideline & No. of Studies & Studies & Comment \\
\hline EULAR & 2 reviews, 313-422 subjects & Roskell, N.S. et al. 2011 [70] & $\begin{array}{c}\text { Meta-analysis. One study on Tramadol. Tramadol plus Paracetamol } \\
\text { was more likely to achieve 30\% improvement in pain (RR 1.77, 95\% } \\
\text { CI 1.26 to 2.48) }(n=313)\end{array}$ \\
\cline { 2 - 3 } AWMF & Choy, E. et al. 2011 [66] & $\begin{array}{c}\text { Meta-analysis, only one study with tramadol (50-400 mg) was } \\
\text { included which showed benefit compared to placebo }\end{array}$ \\
\hline $\begin{array}{c}\text { Canadian } \\
\text { guidelines }\end{array}$ & Bennett, R.M. et al. 2003 [35] & $\begin{array}{c}\text { Double blind, randomised study with 313 participants. A } \\
\text { tramadol/ acetaminophen was effective in treating FM. }\end{array}$ & $\begin{array}{c}\text { Due to the limited data neither a positive nor a } \\
\text { negative recommendation is possible for weak } \\
\text { opioids. Strong consensus. }\end{array}$ \\
\hline
\end{tabular}

Table A7. Non Steroidal Anti-Inflammatory Drugs (NSAIDs)

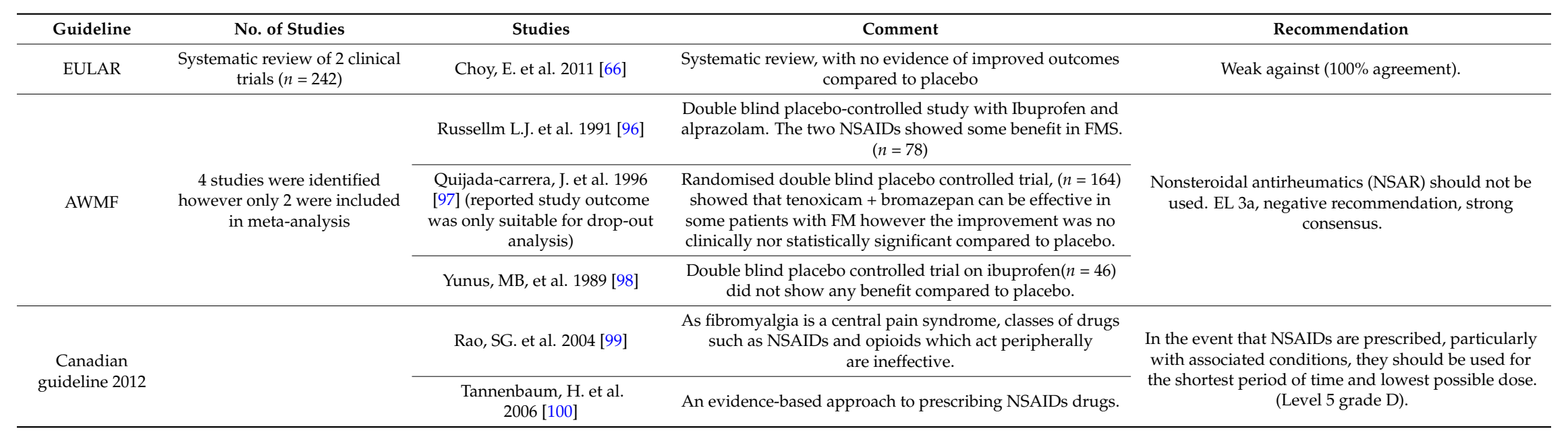




\section{References}

1. Bazzichi, L.; Giacomelli, C.; Consensi, A.; Atzeni, F.; Batticciotto, A.; di Franco, M.; Casale, R.; Sarzi-Puttini, P. One year in review: Fibromyalgia. Clin. Exp. Rheumatol. 2016, 34, S145-S149. [PubMed]

2. Gran, J.T. The epidemiology of chronic generalized musculoskeletal pain. Best Pract. Res. Clin. Rheumatol. 2003, 17, 547-561. [CrossRef]

3. Wolfe, F.; Smythe, H.A.; Yunus, M.B.; Bennett, R.M.; Bombardier, C.; Goldenberg, D.L. The American college of rheumatology 1990 criteria for the classification of fibromyalgia. Report of the multicenter criteria committee. Arthritis Rheum. 1990, 33, 160-172. [CrossRef] [PubMed]

4. Wolfe, F.; Clauw, D.J.; Fitzcharles, M.A.; Goldenberg, D.L.; Katz, R.S.; Mease, P.; Russell, A.S.; Russell, I.J.; Winfield, J.B.; Yunus, M.B. The American college of rheumatology preliminary diagnostic criteria for fibromyalgia and measurement of symptom severity. Arthritis Care Res. 2010, 62, 600-610. [CrossRef] [PubMed]

5. Macfarlane, G.; Kronisch, C.; Dean, L.; Atzeni, F.; Häuser, W.; Fluß, E.; Choy, E.; Kosek, E.; Amris, K.; Branco, J. Eular revised recommendations for the management of fibromyalgia. Ann. Rheum. Dis. 2016. [CrossRef] [PubMed]

6. Carville, S.F.; Arendt-Nielsen, L.; Bliddal, H.; Blotman, F.; Branco, J.C.; Buskila, D.; da Silva, J.A.; Danneskiold-Samsoe, B.; Dincer, F.; Henriksson, C.; et al. Eular evidence-based recommendations for the management of fibromyalgia syndrome. Ann. Rheum. Dis. 2008, 67, 536-541. [CrossRef] [PubMed]

7. Fitzcharles, M.A.; Ste-Marie, P.A.; Goldenberg, D.L.; Pereira, J.X.; Abbey, S.; Choinière, M.; Ko, G.; Moulin, D.E.; Panopalis, P.; Proulx, J.; et al. 2012 Canadian guidelines for the diagnosis and management of fibromyalgia syndrome: Executive summary. Pain Res. Manag. 2013, 18, 119-126. [CrossRef] [PubMed]

8. Fitzcharles, M.A.; Ste Marie, P.A.; Goldenberg, D.L.; Pereira, J.X.; Abbey, S.; Choiniere, M.; Ko, G.; Moulin, D.; Panopalis, P.; Proulx, J.; et al. Canadian Guidelines for the Diagnosis and Management of Fibromyalgia Syndrome. Available online: http:/ / fmguidelines.ca/?page_id=27 (accessed on 2 February 2017).

9. Howick, J.C.I.; Glasziou, P.; Greenhalgh, T.; Heneghan, C.; Liberati, A.; Moschetti, I.; Phillips, B.; Thornton, H.; Goddard, O.; Hogkinson, M. The Oxford 2011 Table of Evidence. Oxford Centre for Evidence-Based Medicine. Available online: http:/ / www.cebm.net/index.aspx?o=5653 (accessed on 2 February 2017).

10. Sommer, C.; Hauser, W.; Alten, R.; Petzke, F.; Spath, M.; Tolle, T.; Uceyler, N.; Winkelmann, A.; Winter, E.; Bar, K.J. Drug therapy of fibromyalgia syndrome. Systematic review, meta-analysis and guideline. Schmerz 2012, 26, 297-310. [CrossRef] [PubMed]

11. Sackett, D.L. Rules of evidence and clinical recommendations on the use of antithrombotic agents. Chest 1986, 89, 25-35. [CrossRef]

12. Härter, M.; Klesse, C.; Bermejo, I.; Lelgemann, M.; Weinbrenner, S.; Ollenschläger, G.; Kopp, I.; Berger, M. Entwicklung der s3-und nationalen versorgungs-leitlinie depression. Bundesgesundheitsblatt-Gesundheitsforschung-Gesundheitsschutz 2008, 51, 451-457. [CrossRef] [PubMed]

13. Nishishinya, B.; Urrútia, G.; Walitt, B.; Rodriguez, A.; Bonfill, X.; Alegre, C.; Darko, G. Amitriptyline in the treatment of fibromyalgia: A systematic review of its efficacy. Rheumatology 2008, 47, 1741-1746. [CrossRef] [PubMed]

14. Taylor, C.P. Mechanisms of analgesia by gabapentin and pregabalin-Calcium channel $\alpha 2-\Delta$ [cav $\alpha 2-\Delta]$ ligands. Pain 2009, 142, 13-16. [CrossRef] [PubMed]

15. Crofford, L.J.; Rowbotham, M.C.; Mease, P.J.; Russell, I.J.; Dworkin, R.H.; Corbin, A.E.; Young, J.P., Jr.; LaMoreaux, L.K.; Martin, S.A.; Sharma, U. Pregabalin for the treatment of fibromyalgia syndrome: Results of a randomized, double-blind, placebo-controlled trial. Arthritis Rheum. 2005, 52, 1264-1273. [CrossRef] [PubMed]

16. Moore, R.A.; Straube, S.; Wiffen, P.J.; Derry, S.; McQuay, H.J. Pregabalin for acute and chronic pain in adults. Cochrane Database Syst. Rev. 2009. [CrossRef]

17. Häuser, W.; Bernardy, K.; Üçeyler, N.; Sommer, C. Treatment of fibromyalgia syndrome with gabapentin and pregabalin-A meta-analysis of randomized controlled trials. Pain 2009, 145, 69-81. [CrossRef] [PubMed]

18. Lamont, L.A.; Tranquilli, W.J.; Grimm, K.A. Physiology of pain. The Veterinary Clinics of North America. Small Anim. Pract. 2000, 30, 703-728. [CrossRef] 
19. Raymond, J.R.; Mukhin, Y.V.; Gelasco, A.; Turner, J.; Collinsworth, G.; Gettys, T.W.; Grewal, J.S.; Garnovskaya, M.N. Multiplicity of mechanisms of serotonin receptor signal transduction. Pharmacol. Ther. 2001, 92, 179-212. [CrossRef]

20. Caspi, A.; Sugden, K.; Moffitt, T.E.; Taylor, A.; Craig, I.W.; Harrington, H.; McClay, J.; Mill, J.; Martin, J.; Braithwaite, A.; et al. Influence of life stress on depression: Moderation by a polymorphism in the 5-HTT gene. Science 2003, 301, 386-389. [CrossRef] [PubMed]

21. Häuser, W.; Petzke, F.; Sommer, C. Comparative efficacy and harms of duloxetine, milnacipran, and pregabalin in fibromyalgia syndrome. J. Pain 2010, 11, 505-521. [CrossRef] [PubMed]

22. Lunn, M.P.; Hughes, R.A.; Wiffen, P.J. Duloxetine for treating painful neuropathy, chronic pain or fibromyalgia. Cochrane Database Syst. Rev. 2014. [CrossRef]

23. Derry, S.; Gill, D.; Phillips, T.; Moore, R.A. Milnacipran for neuropathic pain and fibromyalgia in adults. Cochrane Database Syst. Rev. 2012, 14. [CrossRef]

24. Ormseth, M.J.; Eyler, A.E.; Hammonds, C.L.; Boomershine, C.S. Milnacipran for the management of fibromyalgia syndrome. J. Pain Res. 2010, 3, 15-24. [PubMed]

25. Mease, P.J.; Clauw, D.J.; Gendreau, R.M.; Rao, S.G.; Kranzler, J.; Chen, W.; Palmer, R.H. The efficacy and safety of milnacipran for treatment of fibromyalgia. A randomized, double-blind, placebo-controlled trial. J. Rheumatol. 2009, 36, 398-409. [CrossRef] [PubMed]

26. Clauw, D.J.; Mease, P.; Palmer, R.H.; Gendreau, R.M.; Wang, Y. Milnacipran for the treatment of fibromyalgia in adults: A 15-week, multicenter, randomized, double-blind, placebo-controlled, multiple-dose clinical trial. Clin. Ther. 2008, 30, 1988-2004. [CrossRef] [PubMed]

27. Hauser, W.; Urrutia, G.; Tort, S.; Uceyler, N.; Walitt, B. Serotonin and noradrenaline reuptake inhibitors (snris) for fibromyalgia syndrome. Cochrane Database Syst. Rev. 2013. [CrossRef]

28. Walitt, B.; Urrútia, G.; Nishishinya, M.B.; Cantrell, S.E.; Häuser, W. Selective serotonin reuptake inhibitors for fibromyalgia syndrome. Cochrane Database Syst. Rev. 2015, 6. [CrossRef]

29. Goldenberg, D.; Mayskiy, M.; Mossey, C.; Ruthazer, R.; Schmid, C. A randomized, double-blind crossover trial of fluoxetine and amitriptyline in the treatment of fibromyalgia. Arthritis Rheum. 1996, 39, 1852-1859. [CrossRef] [PubMed]

30. Wolfe, F.; Cathey, M.; Hawley, D. A double-blind placebo controlled trial of fluoxetine in fibromyalgia. Scand. J. Rheumatol. 1994, 23, 255-259. [CrossRef] [PubMed]

31. Anderberg, U.M.; Marteinsdottir, I.; Knorring, L. Citalopram in patients with fibromyalgia-A randomized, double-blind, placebo-controlled study. Eur. J. Pain 2000, 4, 27-35. [CrossRef] [PubMed]

32. Baraniuk, J.N.; Whalen, G.; Cunningham, J.; Clauw, D.J. Cerebrospinal fluid levels of opioid peptides in fibromyalgia and chronic low back pain. BMC Musculoskelet. Disord. 2004, 5, 48. [CrossRef] [PubMed]

33. Harris, R.E.; Clauw, D.J.; Scott, D.J.; McLean, S.A.; Gracely, R.H.; Zubieta, J.K. Decreased central mu-opioid receptor availability in fibromyalgia. J. Neurosci. 2007, 27, 10000-10006. [CrossRef] [PubMed]

34. Ngian, G.S.; Guymer, E.K.; Littlejohn, G.O. The use of opioids in fibromyalgia. Int. J. Rheum. Dis. 2011, 14, 6-11. [CrossRef] [PubMed]

35. Bennett, R.M.; Kamin, M.; Karim, R.; Rosenthal, N. Tramadol and acetaminophen combination tablets in the treatment of fibromyalgia pain: A double-blind, randomized, placebo-controlled study. Am. J. Med. 2003, 114, 537-545. [CrossRef]

36. Bennett, R.M.; Schein, J.; Kosinski, M.R.; Hewitt, D.J.; Jordan, D.M.; Rosenthal, N.R. Impact of fibromyalgia pain on health-related quality of life before and after treatment with tramadol/acetaminophen. Arthritis Care Res. 2005, 53, 519-527. [CrossRef] [PubMed]

37. Biasi, G.; Manca, S.; Manganelli, S.; Marcolongo, R. Tramadol in the fibromyalgia syndrome: A controlled clinical trial versus placebo. Int. J. Clin. Pharmacol. Res. 1998, 18, 13-19. [PubMed]

38. Russell, I.J.; Kamin, M.; Bennett, R.M.; Schnitzer, T.J.; Green, J.A.; Katz, W.A. Efficacy of tramadol in treatment of pain in fibromyalgia. J. Clin. Rheumatol. 2000, 6, 250-257. [CrossRef] [PubMed]

39. Gregori-Puigjané, E.; Setola, V.; Hert, J.; Crews, B.A.; Irwin, J.J.; Lounkine, E.; Marnett, L.; Roth, B.L.; Shoichet, B.K. Identifying mechanism-of-action targets for drugs and probes. Proc. Natl. Acad. Sci. USA 2012, 109, 11178-11183. [CrossRef] [PubMed]

40. Tofferi, J.K.; Jackson, J.L.; O'malley, P.G. Treatment of fibromyalgia with cyclobenzaprine: A meta-analysis. Arthritis Care Res. 2004, 51, 9-13. [CrossRef] [PubMed] 
41. Hauser, W.; Walitt, B.; Fitzcharles, M.A.; Sommer, C. Review of pharmacological therapies in fibromyalgia syndrome. Arthritis Res. Ther. 2014, 16, 201. [CrossRef] [PubMed]

42. Herkenham, M.; Lynn, A.B.; Johnson, M.R.; Melvin, L.S.; de Costa, B.R.; Rice, K.C. Characterization and localization of cannabinoid receptors in rat brain: A quantitative in vitro autoradiographic study. J. Neurosci. 1991, 11, 563-583. [PubMed]

43. Manzanares, J.; Julian, M.; Carrascosa, A. Role of the cannabinoid system in pain control and therapeutic implications for the management of acute and chronic pain episodes. Curr. Neuropharmacol. 2006, 4, $239-257$. [CrossRef] [PubMed]

44. Ware, M.A.; St Arnaud-Trempe, E. The abuse potential of the synthetic cannabinoid nabilone. Addiction (Abingdon Engl.) 2010, 105, 494-503. [CrossRef] [PubMed]

45. Derry, S.; Wiffen, P.J.; Häuser, W.; Mücke, M.; Tölle, T.R.; Bell, R.F.; Moore, R.A. Oral nonsteroidal anti-inflammatory drugs for fibromyalgia in adults. Cochrane Lib. 2016. [CrossRef]

46. Hogestatt, E.D.; Jonsson, B.A.; Ermund, A.; Andersson, D.A.; Bjork, H.; Alexander, J.P.; Cravatt, B.F.; Basbaum, A.I.; Zygmunt, P.M. Conversion of acetaminophen to the bioactive $N$-acylphenolamine am404 via fatty acid amide hydrolase-dependent arachidonic acid conjugation in the nervous system. J. Biol. Chem. 2005, 280, 31405-31412. [CrossRef] [PubMed]

47. Gould, G.G.; Seillier, A.; Weiss, G.; Giuffrida, A.; Burke, T.F.; Hensler, J.G.; Rock, C.; Tristan, A.; McMahon, L.R.; Salazar, A.; et al. Acetaminophen differentially enhances social behavior and cortical cannabinoid levels in inbred mice. Prog. Neuro-Psychopharmacol. Biol. Psychiatry 2012, 38, 260-269. [CrossRef] [PubMed]

48. Mease, P.; Arnold, L.M.; Choy, E.H.; Clauw, D.J.; Crofford, L.; Glass, J.M.; Martin, S.A.; Morea, J.; Simon, L.; Strand, V.; et al. Fibromyalgia syndrome module at omeract 9. J. Rheumatol. 2009, 36, 2318-2329. [CrossRef] [PubMed]

49. Hauser, W.; Petzke, F.; Uceyler, N.; Sommer, C. Comparative efficacy and acceptability of amitriptyline, duloxetine and milnacipran in fibromyalgia syndrome: A systematic review with meta-analysis. Rheumatology (Oxford) 2011, 50, 532-543. [CrossRef] [PubMed]

50. Üçeyler, N.; Häuser, W.; Sommer, C. A systematic review on the effectiveness of treatment with antidepressants in fibromyalgia syndrome. Arthritis Care Res. 2008, 59, 1279-1298. [CrossRef] [PubMed]

51. Moore, R.A.; Derry, S.; Aldington, D.; Cole, P.; Wiffen, P.J. Amitriptyline for neuropathic pain and fibromyalgia in adults. Cochrane Lib. 2012. [CrossRef]

52. Perrot, S.; Russell, I. More ubiquitous effects from non-pharmacologic than from pharmacologic treatments for fibromyalgia syndrome: A meta-analysis examining six core symptoms. Eur. J. Pain 2014, 18, 1067-1080. [CrossRef] [PubMed]

53. Çapaci, K.; Hepgüler, S. Comparison of the effects of amitriptyline and paroxetine in the treatment of fibromyalgia syndrome. Pain Clin. 2002, 14, 223-228. [CrossRef]

54. Carette, S.; McCain, G.A.; Bell, D.A.; Fam, A.G. Evaluation of amitriptyline in primary fibrositis. A double-blind, placebo-controlled study. Arthritis Rheumatol. 1986, 29, 655-659. [CrossRef]

55. Carette, S.; Bell, M.J.; Reynolds, W.J.; Haraoui, B.; Mccain, G.A.; Bykerk, V.P.; Edworthy, S.M.; Baron, M.; Koehler, B.E.; Fam, A.G. Comparison of amitriptyline, cyclobenzaprine, and placebo in the treatment of fibromyalgia. Arthritis Rheum. 1994, 37, 32-40. [CrossRef] [PubMed]

56. Carette, S.; Oakson, G.; Guimont, C.; Steriade, M. Sleep electroencephalography and the clinical response to amitriptyline in patients with fibromyalgia. Arthritis Rheum. 1995, 38, 1211-1217. [CrossRef] [PubMed]

57. Caruso, I.; Sarzi Puttini, P.C.; Boccassini, L.; Santandrea, S.; Locati, M.; Volpato, R.; Montrone, F.; Benvenuti, C.; Beretta, A. Double-blind study of dothiepin versus placebo in the treatment of primary fibromyalgia syndrome. J. Int. Med. Res. 1987, 15, 154-159. [CrossRef] [PubMed]

58. Garcia, J.; Simon, M.A.; Duran, M.; Canceller, J.; Aneiros, F.J. Differential efficacy of a cognitive-behavioral intervention versus pharmacological treatment in the management of fibromyalgic syndrome. Psychol. Health Med. 2006, 11, 498-506. [CrossRef] [PubMed]

59. Ginsberg, F.; Mancaux, A.; Joos, E.; Vanhove, P.; Famaey, J.-P. A randomized placebo-controlled trial of sustained-release amitriptyline in primary fibromyalgia. J. Musculoskelet. Pain 1996, 4, 37-47. [CrossRef]

60. Goldenberg, D.L.; Felson, D.T.; Dinerman, H. A randomized, controlled trial of amitriptyline and naproxen in the treatment of patients with fibromyalgia. Arthritis Rheum. 1986, 29, 1371-1377. [CrossRef] [PubMed] 
61. Hannonen, P.; Malminiemi, K.; Yli-Kerttula, U.; Isomeri, R.; Roponen, P. A randomized, double-blind, placebo-controlled study of moclobemide and amitriptyline in the treatment of fibromyalgia in females without psychiatric disorder. Rheumatology 1998, 37, 1279-1286. [CrossRef]

62. Heymann, R.; Helfenstein, M.; Feldman, D. A double-blind, randomized, controlled study of amitriptyline, nortriptyline and placebo in patients with fibromyalgia. An analysis of outcome measures. Clin. Exp. Rheumatol. 2001, 19, 697-702. [PubMed]

63. Kempenaers, C.; Simenon, G.; Vander Elst, M.; Fransolet, L.; Mingard, P.; De Maertelaer, V.; Appelboom, T.; Mendlewicz, J. Effect of an antidiencephalon immune serum on pain and sleep in primary fibromyalgia. Neuropsychobiology 1994, 30, 66-72. [CrossRef] [PubMed]

64. Scudds, R.A.; McCain, G.; Rollman, G.; Harth, M. Improvements in pain responsiveness in patients with fibrositis after successful treatment with amitriptyline. J. Rheumatol. Suppl. 1989, 19, 98-103. [PubMed]

65. Hauser, W.; Bernardy, K.; Uceyler, N.; Sommer, C. Treatment of fibromyalgia syndrome with antidepressants: A meta-analysis. JAMA 2009, 301, 198-209. [CrossRef] [PubMed]

66. Choy, E.; Marshall, D.; Gabriel, Z.L.; Mitchell, S.A.; Gylee, E.; Dakin, H.A. A systematic review and mixed treatment comparison of the efficacy of pharmacological treatments for fibromyalgia. Semin. Arthritis Rheum. 2011, 41, 335-345. [CrossRef] [PubMed]

67. Tzellos, T.G.; Toulis, K.A.; Goulis, D.G.; Papazisis, G.; Zampeli, V.A.; Vakfari, A.; Kouvelas, D. Gabapentin and pregabalin in the treatment of fibromyalgia: A systematic review and a meta-analysis. J. Clin. Pharmacy Therap. 2010, 35, 639-656. [CrossRef] [PubMed]

68. Uceyler, N.; Sommer, C.; Walitt, B.; Hauser, W. Anticonvulsants for fibromyalgia. Cochrane Database Syst. Rev. 2013. [CrossRef]

69. Siler, A.C.; Gardner, H.; Yanit, K.; Cushman, T.; McDonagh, M. Systematic review of the comparative effectiveness of antiepileptic drugs for fibromyalgia. J. Pain 2011, 12, 407-415. [CrossRef] [PubMed]

70. Roskell, N.S.; Beard, S.M.; Zhao, Y.; Le, T.K. A meta-analysis of pain response in the treatment of fibromyalgia. Pain Pract. 2011, 11, 516-527. [CrossRef] [PubMed]

71. Arnold, L.M.; Russell, I.J.; Diri, E.W.; Duan, W.R.; Young, J.P., Jr.; Sharma, U.; Martin, S.A.; Barrett, J.A.; Haig, G. A 14-week, randomized, double-blinded, placebo-controlled monotherapy trial of pregabalin in patients with fibromyalgia. J. Pain 2008, 9, 792-805. [CrossRef] [PubMed]

72. Mease, P.J.; Russell, I.J.; Arnold, L.M.; Florian, H.; Young, J.P.; Martin, S.A.; Sharma, U. A randomized, double-blind, placebo-controlled, phase III trial of pregabalin in the treatment of patients with fibromyalgia. J. Rheumatol. 2008, 35, 502-514. [PubMed]

73. Arnold, L.M.; Goldenberg, D.L.; Stanford, S.B.; Lalonde, J.K.; Sandhu, H.S.; Keck, P.E., Jr.; Welge, J.A.; Bishop, F.; Stanford, K.E.; Hess, E.V.; et al. Gabapentin in the treatment of fibromyalgia: A randomized, double-blind, placebo-controlled, multicenter trial. Arthritis Rheum. 2007, 56, 1336-1344. [CrossRef] [PubMed]

74. Holtedahl, R. Questionable documentation of the effect of pregabalin in fibromyalgia. Tidsskr Nor Laegeforen 2010, 130, 1032-1036. [CrossRef] [PubMed]

75. Bennett, R.M.; Gatter, R.A.; Campbell, S.M.; Andrews, R.P.; Clark, S.R.; Scarola, J.A. A comparison of cyclobenzaprine and placebo in the management of fibrositis. Arthritis Rheum. 1988, 31, 1535-1542. [CrossRef] [PubMed]

76. Hamaty, D.; Valentine, J.; Howard, R.; Howard, C.; Wakefield, V.; Patten, M. The plasma endorphin, prostaglandin and catecholamine profile of patients with fibrositis treated with cyclobenzaprine and placebo: A 5-month study. J. Rheumatol. Suppl. 1989, 19, 164-168. [PubMed]

77. Reynolds, W.; Moldofsky, H.; Saskin, P.; Lue, F. The effects of cyclobenzaprine on sleep physiology and symptoms in patients with fibromyalgia. J. Rheumatol. 1991, 18, 452-454. [PubMed]

78. Häuser, W.; Wolfe, F.; Tölle, T.; Üçeyler, N.; Sommer, C. The role of antidepressants in the management of fibromyalgia syndrome. CNS Drugs 2012, 26, 297-307. [CrossRef] [PubMed]

79. Jung, A.C.; Staiger, T.; Sullivan, M. The efficacy of selective serotonin reuptake inhibitors for the management of chronic pain. J. Gen. Intern. Med. 1997, 12, 384-389. [CrossRef] [PubMed]

80. Arnold, L.M.; Keck, P.E., Jr.; Welge, J.A. Antidepressant treatment of fibromyalgia. A meta-analysis and review. Psychosomatics 2000, 41, 104-113. [CrossRef] [PubMed] 
81. Arnold, L.M.; Hess, E.V.; Hudson, J.I.; Welge, J.A.; Berno, S.E.; Keck, P.E., Jr. A randomized, placebo-controlled, double-blind, flexible-dose study of fluoxetine in the treatment of women with fibromyalgia. Am. J. Med. 2002, 112, 191-197. [CrossRef]

82. Nørregaard, J.; Volkmann, H.; Danneskiold-Samstøe, B. A randomized controlled trial of citalopram in the treatment of fibromyalgia. Pain 1995, 61, 445-449. [CrossRef]

83. Sencan, S.; Ak, S.; Karan, A.; Muslumanoglu, L.; Ozcan, E.; Berker, E. A study to compare the therapeutic efficacy of aerobic exercise and paroxetine in fibromyalgia syndrome. J. Back Musculoskelet. Rehabil. 2004, 17, 57-61. [CrossRef]

84. Patkar, A.A.; Masand, P.S.; Krulewicz, S.; Mannelli, P.; Peindl, K.; Beebe, K.L.; Jiang, W. A randomized, controlled, trial of controlled release paroxetine in fibromyalgia. Am. J. Med. 2007, 120, 448-454. [CrossRef] [PubMed]

85. Distler, O.; Eich, W.; Dokoupilova, E.; Dvorak, Z.; Fleck, M.; Gaubitz, M.; Hechler, M.; Jansen, J.P.; Krause, A.; Bendszus, M.; et al. Evaluation of the efficacy and safety of terguride in patients with fibromyalgia syndrome: Results of a twelve-week, multicenter, randomized, double-blind, placebo-controlled, parallel-group study. Arthritis Rheum. 2010, 62, 291-300. [CrossRef] [PubMed]

86. Häuser, W.; Bernardy, K.; Arnold, B.; Offenbächer, M.; Schiltenwolf, M. Efficacy of multicomponent treatment in fibromyalgia syndrome: A meta-analysis of randomized controlled clinical trials. Arthritis Rheum. 2009, 61, 216-224. [CrossRef] [PubMed]

87. Sultan, A.; Gaskell, H.; Derry, S.; Moore, R.A. Duloxetine for painful diabetic neuropathy and fibromyalgia pain: Systematic review of randomised trials. BMC Neurol. 2008, 8, 29. [CrossRef] [PubMed]

88. Arnold, L.M.; Lu, Y.; Crofford, L.J.; Wohlreich, M.; Detke, M.J.; Iyengar, S.; Goldstein, D.J. A double-blind, multicenter trial comparing duloxetine with placebo in the treatment of fibromyalgia patients with or without major depressive disorder. Arthritis Rheum. 2004, 50, 2974-2984. [CrossRef] [PubMed]

89. Arnold, L.M.; Rosen, A.; Pritchett, Y.L.; D'Souza, D.N.; Goldstein, D.J.; Iyengar, S.; Wernicke, J.F. A randomized, double-blind, placebo-controlled trial of duloxetine in the treatment of women with fibromyalgia with or without major depressive disorder. Pain 2005, 119, 5-15. [CrossRef] [PubMed]

90. Arnold, L.M.; Clauw, D.; Wang, F.; Ahl, J.; Gaynor, P.J.; Wohlreich, M.M. Flexible dosed duloxetine in the treatment of fibromyalgia: A randomized, double-blind, placebo-controlled trial. J. Rheumatol. 2010, 37, 2578-2586. [CrossRef] [PubMed]

91. Chappell, A.S.; Bradley, L.A.; Wiltse, C.; Detke, M.J.; D'Souza, D.N.; Spaeth, M. A six-month double-blind, placebo-controlled, randomized clinical trial of duloxetine for the treatment of fibromyalgia. Int. J. Gen. Med. 2008, 1, 91-102. [CrossRef] [PubMed]

92. Russell, I.J.; Mease, P.J.; Smith, T.R.; Kajdasz, D.K.; Wohlreich, M.M.; Detke, M.J.; Walker, D.J.; Chappell, A.S.; Arnold, L.M. Efficacy and safety of duloxetine for treatment of fibromyalgia in patients with or without major depressive disorder: Results from a 6-month, randomized, double-blind, placebo-controlled, fixed-dose trial. Pain 2008, 136, 432-444. [CrossRef] [PubMed]

93. Arnold, L.M.; Gendreau, R.M.; Palmer, R.H.; Gendreau, J.F.; Wang, Y. Efficacy and safety of milnacipran $100 \mathrm{mg} /$ day in patients with fibromyalgia: Results of a randomized, double-blind, placebo-controlled trial. Arthritis Rheum. 2010, 62, 2745-2756. [CrossRef] [PubMed]

94. Branco, J.C.; Zachrisson, O.; Perrot, S.; Mainguy, Y. A european multicenter randomized double-blind placebo-controlled monotherapy clinical trial of milnacipran in treatment of fibromyalgia. J. Rheumatol. 2010, 37, 851-859. [CrossRef] [PubMed]

95. Vitton, O.; Gendreau, M.; Gendreau, J.; Kranzler, J.; Rao, S.G. A double-blind placebo-controlled trial of milnacipran in the treatment of fibromyalgia. Hum. Psychopharmacol. 2004, 19, S27-S35. [CrossRef] [PubMed]

96. Russell, I.J.; Fletcher, E.M.; Michalek, J.E.; McBroom, P.C.; Hester, G. Treatment of primary fibrositis/fibromyalgia syndrome with ibuprofen and alprazolam. A double-blind, placebo-controlled study. Arthritis Rheumatol. 1991, 34, 552-560. [CrossRef]

97. Quijada-Carrera, J.; Valenzuela-Castaño, A.; Povedano-Gómez, J.; Fernández-Rodriguez, A.; Hernánz-Mediano, W.; Gutierrez-Rubio, A.; De la Iglesia-Salgado, J.L.; García-López, A. Comparison of tenoxicam and bromazepan in the treatment of fibromyalgia: A randomized, double-blind, placebo-controlled trial. Pain 1996, 65, 221-225. [CrossRef]

98. Yunus, M.; Masi, A.T.; Aldag, J. Short term effects of ibuprofen in primary fibromyalgia syndrome: A double blind, placebo controlled trial. J. Rheumatol. 1989, 16, 527-532. [PubMed] 
99. Rao, S.G.; Clauw, D.J. The management of fibromyalgia. Drugs Today (Barcelona Spain 1998) 2004, 40, 539-554. [CrossRef]

100. Tannenbaum, H.; Bombardier, C.; Davis, P.; Russell, A.S. Third Canadian Consensus Conference Group An evidence-based approach to prescribing nonsteroidal antiinflammatory drugs. Third canadian consensus conference. J. Rheumatol. 2006, 33, 140-157. [PubMed] 